\title{
THE IMPACT OF TOURISM WITH VACATION HOMES (SECOND HOMES) ON THE NATURAL ENVIRONMENT AT THE FÂNTÂNELE RESERVOIR- APUSENI NATURE PARK
}

\author{
Ioana Alexandra CIUPE ${ }^{1}$, Laura Andreea $L A Z \breve{A} R^{1}$
}

\begin{abstract}
The impact of tourism with vacation homes (second homes) on the rural environment at the Fântânele Reservoir- Apuseni Nature Park. The quality of the natural landscape and the presence of Fântânele Reservoir, have long been identified as one of the key motives for second home tourism - as one of the patterns of tourism development - in Cluj county from Apuseni Nature Park. Given the fact that lately, the number of vacation homes (second homes) is continuously increasing, this generates negative effects on the natural environment both of its construction and use. Therefore, this is the reason why the study proposes to identify, analyses and exemplify the main tendency of vacation home (second home) tourism and its environmental impact with direct reference to Fântanele Reservoir located in Apuseni Nature Park. The study used a methodology that involved a direct research on the field, inventory of the number of second homes and geospatial analysis through processing and interpretation of data obtained, in the form of cartographic support. The results indicate that majority of second home are located in vulnerable natural areas, in inappropriate places, without respect any legislation restriction imposed by natural area status.
\end{abstract}

Keywords: Lake tourism, vacation homes, natural environmental impact

\section{INTRODUCTION}

The vacation homes definition (second homes) differs from country to country, but in the current study they refer to homes owned by people coming generally from urban areas and represent „home for rest and recreation, which at the time of the census may be empty or occupied by the persons wich are temporarily present” (Romanian census definitions, 2011).

The tourism with second homes appears in Romania especially after 1990s, in the context of changes in the socio-economic and political system and that are considered a trait of particular initiatives liberalization (Ciangă, 2006, p. 158).

In terms of localization, second home owners prefer peripheral amenity rich area in the heart of nature, rural landscapes, amenity-rich hinterlands of metropolitan areas, major holiday destinations, purpose-built resort regions (Ciangă, 2007, Pitkänen, 2008, Müller, 2006, Adamiak et al. 2016, Adamiak, 2016), and are also a few studies related to presence of those second homes around reservoirs (Long and Hoogendoorn, 2013, Mika, 2013).

${ }^{1}$ Babeș-Bolyai University, Faculty of Geography, 400006 Cluj-Napoca, România, e-mail: alexandra.ciupe@yahoo.com, lazarlaura90@yahoo.com 
The tourism which is made in the proximity of lakes (also called Lake Tourism or Water Tourism) is considered by some authors a distinct branch of tourism and one of the most sensitive due to the peculiarities of the environment: water tourism and recreational activity is a threat to the most environmentally sensitive lakes (Kurleto, 2013, p. 94).

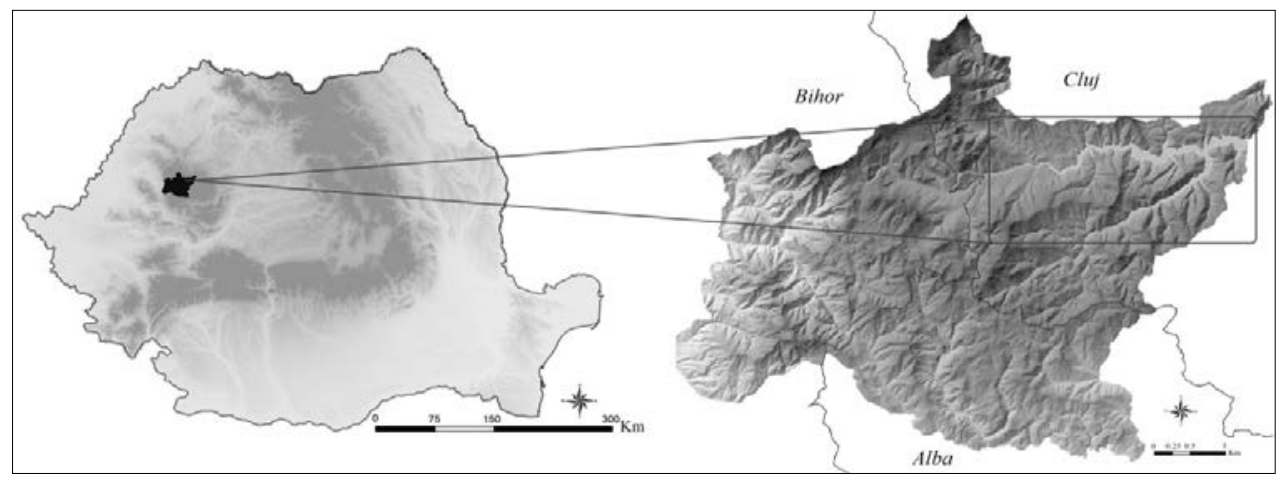

Fig. 1. The location of Fântânele Reservoir

Apuseni Natural Park, with an total area of 75.784 ha, established by L. $5 / 2000$ on the approval of the National Landscaping - Section III - protected areas, and designated as a natural park by GD 230/2003, VIUCN category - Protected Landscape / Seascape, covers a partial area from the Cluj, Bihor and Alba counties (38\% Cluj, Bihor 36\%, 26\% Alba- according to calculations made in ArcGIS, 10.2). Fantanele Reservoir spans an area of approx. 3\% of Cluj County, included in the PNAp, it is administered by the National Administration „Romanian Waters“, and the localities from the vicinity of the Apuseni Nature Park are administrated by the local governments of communes Beliș, Mărgău and Râșca, with the Apuseni Natural Park Administration. In terms of delimitation in management areas of PNAp, Fantanele Reservoir and extravilan areas around him are included in the sustainable management area Resort Fantanele, and the villages of his proximity are included in the area of Sustainable development of human activities (Management Plan Apuseni Nature Park, 2006). Also, Fântânele Reservoir and the adjacent areas (except the village Beliş) are included in ROSCI0002 Apuseni and ROSPA0081 (except the intravilan of the localities Bălceşti, Beliş, Dealu Botii and Fântânele Resort).

\section{MATERIALS AND METHODS}

Natural environmental impact was recognized over the time in the international research, because the most of the vacation homes are located in the vulnerable natural area, distinguishing himself impacts predominantly negative related to: wildlife disruption due to clearance of vegetation, human waste, aesthetics, urbanisation of mountain areas and change in land use, pollution from septic tanks, poor maintenance of second homes compared with main residences and so on (Norris and Winston, 2009, Müller et al, 2004, Mika, 2013). 
The present study aimed to capture of the vacation home tourism from the Fantanele Reservoir area the risks and the impacts on the natural environment through a long field research, where were obtained qualitative as well as quantitative results. The inventory of second homes was restored later in the form of mapping on using the Point Density in ArcGIS 10.2 software, just for the purpose of facilitating a better visualization and to capture the phenomenon in terms of spatially consistent with the main sources of water in the Lake Fantanele area. Since this study is about the tourism, by the evaluation of the impact and of the risks caused by the tourism with second homes on the natural environment, were consulted bibliography of related fields.

\section{RESULTS AND DISCUSSIONS}

According to Romanian census of population and housing of 2011, in Apuseni Nature Park were 1654 vacation homes of wich 11\% in Alba county, 28\% Bihor county and $61 \%$ in Cluj County. The main reasons because Cluj County has the highest proportion of vacation homes are Fântânele Reservoir and a good accessibility from Cluj-Napoca city.

The impact of tourism with second homes in the Lake Fântanele area on the natural environment is related to: the impact of building and maintaining construction (second home), the impact of necessary facilities to perform activities, the impact of activities performed and the impact in terms of localization (at catchment areas or proximity of the lake).

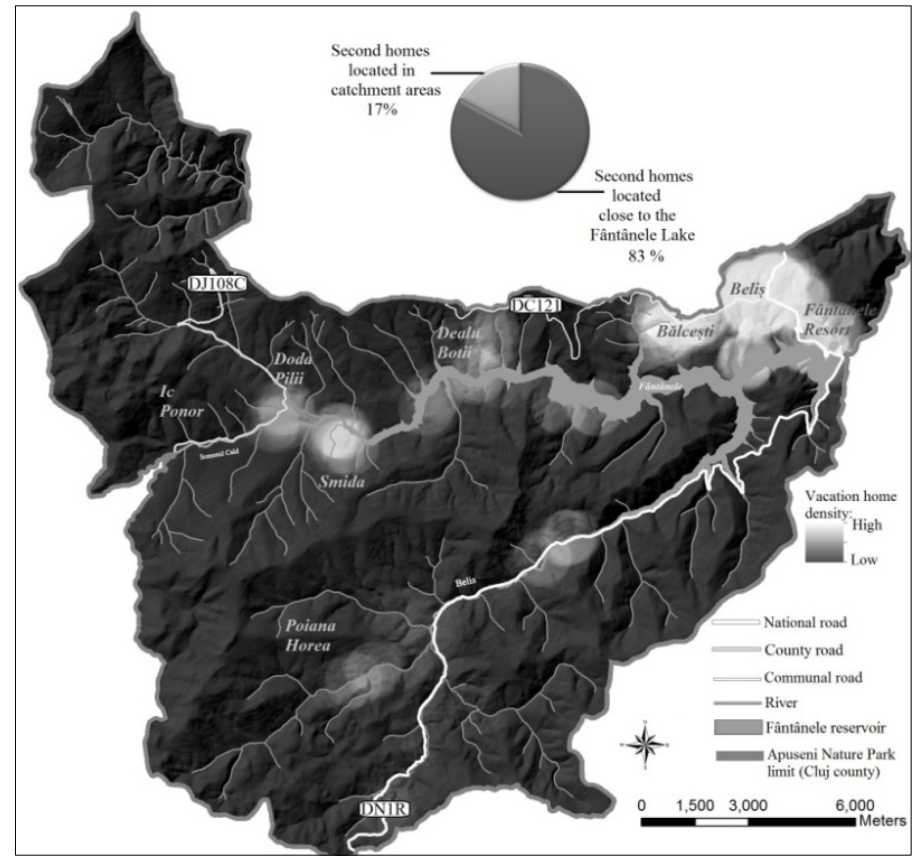

Fig. 2. Spatial distribution of second homes, Apuseni Nature Park, Cluj County 


\subsection{The impact of the second home as a physical structure}

The negative consequences of the vacation homes start since they are build (noise pollution and wildlife distruption, risk of water contamination by industrial waste, etc.). By increasing the number of the constructions, there are extended the soil sealing effect (covering the soil with impermeable surfaces), a phenomenon that leads to reduction of areas of fertile land, favors the risk of flooding, lack of drinking water resources or climatic changes (source: ec.europa.eu). Besides, in the studied area, sometimes it is used construction materials, that does not integrate in landscape, resulting a unsightly landscape urbanization aspect (Fig. 3).

Another common problem is localisation of the second home on the shoreline, often disregard the protective area established by L. Waters 107/1996. Thus, besides the risk of flooding the second homes, this aspect is one of the main causes of erosion shoreline, losses and fragmentation of terrestrial habitats (Ontario Ministry of Natural Resource, 2013), creating one chain of buildings with a major negative aesthetic impact and deprivation of the access to the lake.

Also, usually the build of the second homes on the shoreline of the lake, requiring removal of vegetation for a better visibility, going over the ecological value of it, therefore, deforestation in the perimeter area lakes produce ecological damage and dust that with garbage from anthropogenic sources and other organic substances in vegetation cover in water reservoirs penetrated determine impact on aquatic ecosystems (Fetke, $2016 \mathrm{PhD}$ thesis summary).

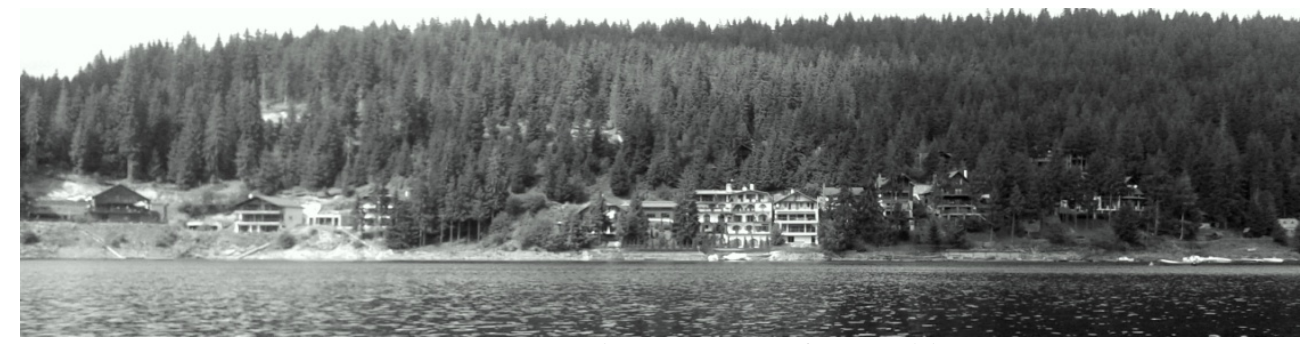

Fig. 3. Negative aesthetic impact of second home

\subsection{The impact of touristic and non-touristic facilities of second homes}

The most important in terms of negative effects on the natural environment are non-existent sewage system and replacing with the poor septic system, which due to the location of the second homes in areas difficult to access, or because an rapidity of the increase in their number in terms of limited funds of the local authorities to investment in expanding of urban infrastructure (Mika, 2013), are the most important sources of bacteria and algae, and the main source of phosphorus and nutrients into the ecosystem of lakes, attracting consequences that ultimately turn into eutrophication (Ontario Ministry of Natural Resource, 2013).

Roads access is a factor that favors the increasing the number of the second homes (ex. the Belis locality, who holds the highest number of second homes in the study area - 214, according to census survey 2011- is crossed by the national road $1 \mathrm{R}$ ), but also tourism with the second homes favors the expansion and the 
construction of new roads or the overuse of sensitive forest roads and the entrance in sensitive remote areas by car to second home. According to Sthephen et al, (2000) the roads which cross the ecosystems can be the cause of animals mortality, animals behavior modification, disruption of the physical environment, altering of the chemical environment (in case of aquatic environment), the spread of exotic species, favoring hunting and fishing (legal or illegal).

Waste management is deficient in the studied area, in this case besides the risk of pollution by disposing of household waste in the natural environment, another factor that can have negative consequences for wildlife is feeding of wild animals with anthropogenic food, that causing their behavioral or nutritional changes (Marzano \& Dandy, 2012).

Arrangement
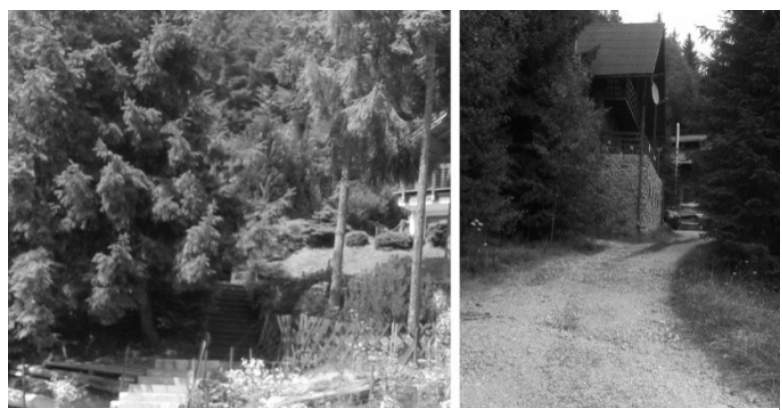

of

gardens can helps to the beautify of the natural

Fig. 4. Example of facilities with negative impact on natural environment (left-stairs for lake access, rightroads access expansion)

environment but the introduction of non-native species and the use of synthetic fertilizers in the gardens can have negative consequences on the natural environment. Also, the structures that facilitates the access to the boats, terraces near the second homes with a chaotic organization, can bring serious consequences on soil surface (Fig. 4, left).

\subsection{The impact of activities}

Conducting the tourism activities of the second homes owners have a high degree of seasonality often visitor access to these lakes is limited to summer months, witch is also the peak of period of biological activity for the local fauna (cited from Kurleto 2013, p. 94 ). So, the intensive fishing and the fishing out the optimum periods may be two potential risks, through the exploitation of the fishing stock, the selection of size and of the species and the introduction of non-indigenous fish species (Dokulil, 2014).

One of the most
damaging tourist activity
especially related to vacation
home tourism and practiced with
intensity in summer season at
Fântânele
Fântânele Lake, is boating

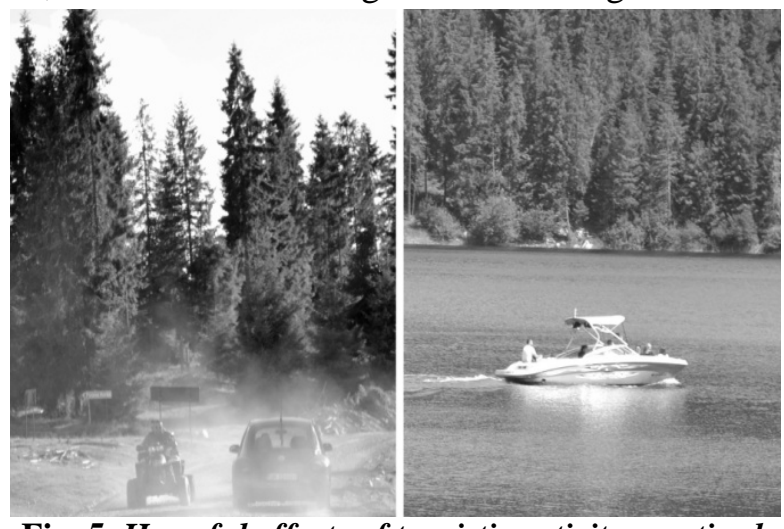

Fig. 5. Harmful effects of touristic activity practiced in Fântanele Reservoir area 
activity. According to Cooper (2006), the negative effects are: noise and air pollution, water pollution, increasing turbidity and shoreline erosion caused by waves created by boats.

\section{CONCLUSION}

The present study has proposed to identify the main impacts and sources of risk on the natural environmental caused by second home tourism developement. The main impacts identified are related to the physical structure of the second home, the necessary utilities and their activities, causing mainly erosion shoreline, deforestation strip of vegetation, the risk of water pollution through the system of sewage faulty, noise pollution, wildlife distruption, etc. Of course, there are impacts positive too, some authors claiming that the owners of the second homes are much better educated ecologically and often are against the development of industrial activities that can bring negative effects of the natural environment (Roca et al, 2011). Also, many authors talk about the impact of tourism activities (Cooper, 2006, Dokulil, 2013) on the natural environment of the area catchment of the watershed (it is important to evaluation and focused attention on catchment areas, because the impact from the chatchment can be significant, that is shows in Fig. 2, there are a significant number of second homes both in the Warm Somes Area (Doda Pilii, Smida localities) as the ones spread along Beliș and its tributaries, and may represent an important source of water pollution that is subsequently transmitted in Fantanele Lake. However, the development of tourism in general can be achieved with a good coordination of the specialists in the field, respecting the sustainable development, and in the case of this study, primarily by establishing a single direction from the local authorities, in order to develop the tourism, to satisfy both tourist demand, but also the need to protect the natural environment.

\section{REFERENCES}

1. Adamiak, C. (2016), Cottage sprawl: Spatial development of second homes in Bory Tucholskie, Poland. Landscape and Urban Planning 147, 96-106.

2. Adamiak, C., Pitkänen, K., Lehtonen, O. (2016), Seasonal residence and counterurbanization: the role of second homes in population redistribution in Finland. GeoJournal 1-16, doi:10.1007/s10708-016-9727-x.

3. Burby III, R.J., Donnelly, T.G., Weiss, S.F. (1972), Vacation home location: a model for simulating the residential development of rural recreation areas. Regional Studies 6, 421-439.

4. Ciangă, N. (2006), România. Geografia turismului, Editura Presa Universitară Clujeană, Cluj-Napoca.

5. Cooper, C. (2006), Lakes as Tourism Destination Resources. In C. Michael Hall and Tuija Harkonen, Lake Tourism: An Integrated Approach to Lacustrine Tourism Systems, Clevedon, United Kingdom: Channel View Publications, 27-44.

6. Dieter K. Müller (2006) The Attractiveness of Second Home Areas in Sweden: A Quantitative Analysis.Current Issues in Tourism 9:4-5, 335-350. 
7. Dokulil, M. T. (2013), Environmental Impacts of Tourism on Lakes. Eutrophication: Causes, Consequences and Control 2, 81-88.

8. Fetke, R. Al. (2016), Influenţe Antropice asupra Populatiilor de Microorganisme din lacurile de Acumulare Secu și Văliug, Jud. Caraş-Severin. Rezumatul Tezei de Doctorat, Universitatea Babeș-Bolyai, Cluj-Napoca.

9. Kurleto, M. (2013), Sustainable Management of Lakes taking into consideration the Tourism and Nature Conservation in Australia and New Zeland. Polish Journal Of Natural Sciences 28:1, 91-106.

10. Long, D., Hoogendoorn G. (2013), Second home owners' perceptions of a polluted environment: The case of Hartbeespoort. South African Geographical Journal 95:1, 91-104.

11. Long, D., Hoogendoorn, G. (2014), Second home owners perceptions of their environmental impact: the case of Hartbeespoort, Urban Forum, 25:4, 517-530.

12. Marzano, M., Dandy, N. (2012), Recreationist behaviour in forests and the disturbance of wildlife. Biodiversity and Conservation 21, 2967-2986.

13. Mirosław, M. (2013), Spatial Patterns of Second Homes Development in the Polish Carpathians, The Carpathians: Integrating Nature and Society Towards Sustainability, Environmental Science and Engineering, 497-512

14. Müller, D. K., Hall, C. M., Keen, D. (2004), Second Home. Tourism. Impact. Planning and. Management. C.M. Hall and D. K. Müller, Tourism, Mobility and Second Home: Between Elite landscapes and Common Ground, Channel View, Clevedon, 15-32.

15. Norris, M., Winston, N. (2009), Rising Second Home Numbers in Rural Ireland: Distribution, Drivers and Implications, European Planning Studies 17:9, 1303-1322.

16. Pitkänen, K. (2008) Second-home Landscape: The Meaning(s) of Landscape for Second-home Tourism in Finnish Lakeland, Tourism Geographies: An International Journal of Tourism Space, Place and Environment 10:2, 169-192.

17. Roca, M. N., Roca, Z., Oliveira, J. A., (2011), Features and Impacts of Second Homes Expansion: the Case of the Oeste Region, Portugal. Hrvatski geografski glasnik 73:2, 111-128

18. Trombulak, S., C., Frissell., C., A. (2000), Review of ecological effects of roads on terrestrial and Aquatic Communities, Conservation Biology 14:1, 18-30.

19. ***(2013) A Summary of Ecological Values and Pressures Associated with Cottage Lot Leases in Algonquin Provincial Park, Ontario Ministry of Natural Resources

20. ***(2006) Planul de Management al Parcului Natural Apuseni, nepublicat

21. ***(2011) Manualul personalului de recensământ, Recensământul Populației și al Locuințelor

22. ***( 2000 ) LEGE Nr. 5privind aprobarea Planului de amenajare a teritoriului naţional - Secţiunea a III-a - zone protejate

23. ***(2003) Hotărârea nr. 230 privind delimitarea rezervaţiilor biosferei, parcurilor naţionale şi parcurilor naturale şi constituirea administraţiilor acestora

24. https://www.iucn.org/theme/protected-areas/about/protected-areacategories/category-v-protected-landscapeseascape

25. http://www.rowater.ro/dasomes/default.aspx

26. http://natura2000.eea.europa.eu/Natura2000/SDF.aspx?site=ROSCI0002

27. http://natura2000.eea.europa.eu/Natura2000/SDF.aspx?site=ROSPA0081

28. http://ec.europa.eu/environment/soil/sealing_guidelines.htm 